\title{
Opportunities to improve nitrogen utilisation in the rumen by reduction in plant-mediated proteolysis
}

\author{
B.A. BARRETT, D.PACHECO, W.C. McNABB and H.S. EASTON \\ AgResearch Ltd., Grasslands Research Centre, Private Bag 11008, Palmerston North, New Zealand \\ brent.barrett@agresearch.co.nz
}

\begin{abstract}
The reaction of ingested forage plant fragments to the rumen environment may contribute to the rapid degradation of plant cell contents in the rumen. A series of experiments were used to explore the hypothesis that plant-mediated proteolysis (PMP) contributes to $\mathrm{N}$ loss from fresh forage entering the rumen, and to investigate the potential for identifying cultivars with reduced PMP. During an in sacco time-course experiment, chopped fresh field grown perennial ryegrass (Lolium perenne L.) leaf samples lost $15 \%$ of their total $\mathrm{N}$ within the first 8 hours in the absence of rumen microbes; whereas $40 \%$ was lost from samples incubated with exposure to rumen microbes. Accumulation of free amino acids in the buffer accounted for $75 \%$ of the $\mathrm{N}$ loss after 24 hours. In a subsequent experiment, in vitro incubation of samples from five perennial ryegrass cultivars detected significant $(\mathrm{P}<0.05)$ differences in the extent of PMP for one cultivar. A further in vitro experiment detected significant $(\mathrm{P}<0.05)$ variation in PMP among ryegrass genotypes $(n=24)$ within two cultivars. Percentage $\mathrm{N}$ loss was not correlated with $\mathrm{N}$ concentration in the fresh forage sample. These data indicate PMP contributes to $\mathrm{N}$ loss from intact fresh plant cells in the rumen, that it is possible to identify cultivars with reduced PMP, and that there may be potential to further reduce PMP by selection within ryegrass populations.
\end{abstract}

Keywords: forage, protein, rumen, proteolysis

\section{Introduction}

Grazed forage is the primary nutrient source for farm animals in New Zealand. Digestive losses of nitrogen (N) occur when the amount of rumen degradable protein ingested exceeds the amount utilised by the rumen microbes. This excess $\mathrm{N}$ is removed from the rumen as ammonia and excreted in the urine after hepatic conversion to urea, at an energetic cost to the animal.

Poor utilisation of protein from pasture is a persistent challenge to science (Ulyatt 1981; Ulyatt 1997). A forage-based means to reduce the high rumen degradability of protein would be a convenient and costeffective way to improve $\mathrm{N}$ utilisation potential. One method proposed to improve $\mathrm{N}$ utilisation is increasing the ratio of fermentable energy to $\mathrm{N}$ in the grazed diet by accumulating fructan to higher levels in perennial ryegrass (Lolium perenne L.). Plants expressing a fructan accumulation trait have been shown to increase $\mathrm{N}$ utilisation, as reviewed in these proceedings (Edwards et al. 2007).

A complementary approach is to reduce the degradability of the herbage protein. Based on this premise, dietary solutions have been proposed. In some forage species condensed tannins protect plant protein during rumen passage, thereby increasing feed conversion efficiency and production (Wang et al. 1996; Woodward et al. 1999). However, the condensed tannins are not expressed at adequate levels in preferred forage species, and as such have seen limited use in New Zealand grazing systems. Polyphenol oxidase has also been shown to form protein-phenol complexes in red clover (Trifolium pratense L.) and cocksfoot (Dactylis glomerata). These complexes stabilise protein in simulated rumen conditions, leading to reduced protein degradability (Lee et al. 2006).

Efforts to improve $\mathrm{N}$ utilisation have also led to investigations into the kinetics and mechanism of protein degradation, including the response by the ingested plant material to the rumen environment. Accumulating research, as recently reviewed by Attwood (2005), indicates a proportion of the proteolysis observed for grazed fresh forage is caused by the plant's own enzymes, in addition to that caused by enzymes of microbial origin (Kingston-Smith et al. 2005).

The initial report investigating forage plant proteases (Zhu et al. 1999) indicated that these enzymes were active in rumen-like conditions (i.e. anaerobic, dark, ca. $39^{\circ} \mathrm{C}$ ), and can rapidly break down a major fraction of the extractable protein into small polypeptides. This has been confirmed in both forage grasses (Beha et al. 2002) and forage legumes (Kingston-Smith et al. 2003) using in vitro incubation assays, and also demonstrated for perennial ryegrass in sacco (Kingston-Smith et al. 2005). This suggests an opportunity for a forage-based means to improve $\mathrm{N}$ utilisation in the rumen, via a reduction in plant-mediated proteolysis (PMP) (Kingston-Smith \& Thomas 2003).

The extent to which PMP contributes to low protein utilisation from New Zealand pasture systems, the proportion of proteolysis it causes in the rumen, and the potential to select forage grass populations with increased protein stability has yet to be explored. 
The objectives of this research were to:

1. Estimate the potential extent and rate of plantmediated and total proteolysis for perennial ryegrass leaf fragments in the dairy rumen.

2. Determine if there is genetic variation in the extent of plant-mediated proteolysis among and within perennial ryegrass cultivars.

\section{Methods \\ Plant material}

All cultivar samples were obtained from a field trial containing single row plots of five perennial ryegrass cultivars, each containing AR1 endophyte. Plots were established from certified seed during the autumn of 2004 in Palmerston North, New Zealand, and maintained by mowing and periodic selective herbicide application to control weeds. For testing PMP in sacco, a bulk of leaf blades from each cultivar was utilised, with equal fresh weight contributions from each cultivar. For cultivar testing in vitro, replicated random sampling of each entry was used to achieve representative samples for each cultivar. For individual genotype testing in vitro, potted plants $(n=12)$ from each of two cultivars were utilised. In all cases, fresh grass leaf blades were manually chopped to $1-2 \mathrm{~cm}$ lengths prior to in sacco and in vitro incubations, as described by Kingston-Smith et al. (2005). A portion (ca. $5 \mathrm{~g}$ fresh weight) of each sample was frozen in liquid $\mathrm{N}$ then freeze dried to provide a time zero estimate of $\mathrm{N}$ concentration and dry matter content.

\section{In sacco experiment}

An experiment was conducted with fresh forage samples to investigate the potential for PMP to contribute to total proteolysis in the rumen of dairy cows. Samples of perennial ryegrass were used in a crossover (two cows, two replicates per cow) experiment to assess the rate of proteolysis in fresh forage fragment samples split between a permeable sac allowing access of rumen microbes (50 micron pore size) and an impermeable polyethylene sac excluding rumen microbes. Autumn regrowth ryegrass samples were harvested at 7:00 am and kept chilled on ice (approx. $\left.4^{\circ} \mathrm{C}\right)$ during sample preparation $(\sim 90$ minutes) prior to incubation in the rumen of fistulated, dry cows. Both the impermeable and permeable sacs were filled with $3 \mathrm{~g}$ of fresh forage $(0.71 \pm 0.01 \mathrm{~g}$ dry weight). Impermeable sacs were subsequently filled with $10 \mathrm{ml}$ of McDougal's buffer (Burke 2004), gassed with carbon dioxide to a $\mathrm{pH}$ of 6.8 , and sealed to provide a similar liquid environment for samples contained in both types of sacs. All sacs were inserted at the same time, and duplicate samples were removed from each cow after $0,1,2,4,6,8,12$, and 24 hours of incubation.

After removal, permeable sacs were washed in coldwater using two successive rinse cycles in a domestic top-loading washing machine (Panasonic, model NA740AZ). For each impermeable polyethylene sac, a subsample of the buffer was obtained for measurement of free amino acid (FAA) concentrations and each sample was subsequently rinsed three times in deionised water to remove buffer residues. Rinsed samples were freeze dried and milled to a fine powder using a modified domestic coffee grinder.

All $\mathrm{N}$ values were determined by combustion (Dumas method AOAC 968.06) using a Carlo Erba Nitrogen Analyser (Carlo Erba Instrumentazione, Milan, Italy). The disappearance of $\mathrm{N}$ was measured as the difference between $\mathrm{N}$ present in the sac at time zero and the amount remaining after incubation in the rumen.

Buffer sampled from recovered polyethylene sacs were analysed for FAA concentration using the ninhydrin assay. Briefly, $0.2 \mathrm{ml}$ buffer was mixed with $0.1 \mathrm{ml}$ of $3 \%$ ninhydrin and $0.1 \mathrm{ml}$ of cyanide acetate buffer and heated in a water bath at $100^{\circ} \mathrm{C}$ for 15 minutes. After cooling at room temperature, the samples were scanned in a spectrophotometer (GBC UV/VIS 918, GBC Scientific Equipment, Dandenong, Australia) at $570 \mathrm{~nm}$ wavelength. The absorbance values were transformed to FAA concentrations using a histidine standard curve.

\section{In vitro experiments}

An experiment was conducted in vitro to compare the extent of PMP in five different perennial ryegrass cultivars using fresh herbage samples harvested in autumn after 3 weeks of regrowth. Duplicate fresh forage samples ( $3 \mathrm{~g}$ fresh weight; $0.70 \pm 0.21 \mathrm{~g}$ dry weight) were incubated in $50 \mathrm{ml}$ sealed glass vials containing 50 $\mathrm{ml}$ of McDougal's buffer (Burke 2004) gassed with carbon dioxide to $\mathrm{pH}$ 6.8. For these experiments, no rumen fluid or rumen microbes were added. Samples were incubated in a Gallenkamp Orbital incubator (Watson Victor, Auckland, NZ) with a darkened incubation chamber maintained at $39^{\circ} \mathrm{C}$ and agitated at $100 \mathrm{rpm}$. Samples were recovered after 24 hours and subjected to the same procedures and measurements as the forage and buffer samples from impermeable sacs in the in sacco experiment.

This in vitro procedure was also used to assess variation in PMP within perennial ryegrass cultivars, using individually potted plants grown from certified seed. Two cultivars were selected from the previous experiment on the basis of divergent PMP levels observed across seasons and years (data not shown). Herbage of 12 individual plants per cultivar was sampled as described above and incubated for 24 hours in vitro.

\section{Statistical analysis}

In situ data were analysed using the MIXED procedure in SAS v 9.1.3 (SAS Institute, 2002). Disappearance of 
$\mathrm{N}$ in the impermeable sac was used as the dependent variable, whilst sac type and incubation day were treated as fixed effects, with repeated measurements over time using the cow as a subject. A simple variance-covariance structure was deemed appropriate by examination of the Akaike's Information Criteria. For the accumulation of FAA in the buffer, a similar analysis was performed after removing the sac effect from the model.

In vitro data were tested by ANOVA implemented in GenStat v9.0, assigning cultivars and individual plants within cultivars as random effects, and glass vials as replicates.

\section{Results and Discussion}

\section{Plant-mediated proteolysis in sacco}

A time-course experiments using chopped fresh perennial ryegrass leaves was used to estimate the potential rate and extent of PMP and of total proteolysis in sacco, by selectively allowing or preventing rumen microbes access to the samples. In the samples incubated in the absence of rumen microbes, approximately $15 \%$ of total $\mathrm{N}$ was lost from the forage within 8 hours. This increased to $20 \%$ after 12 hours and did not increase further during the experiment (Fig. 1).

This result is the first independent confirmation of similar experiments in the United Kingdom which documented PMP in sacco (Kingston-Smith et al. 2005). Our estimate of $20 \%$ total N loss due to PMP after 24 hours is in contrast with published observations that PMP degraded $97 \%$ of extractable (Bradford) protein after 16 hours in sacco (Kingston-Smith et al. 2005). Subsequent measures of protein concentration in our forage samples by Bradford analysis indicated $60 \%$ of extractable protein was degraded by PMP after 24 hours in sacco.

Analysis of the artificial saliva buffer recovered from the impermeable sacs in the time course demonstrated that the loss of $\mathrm{N}$ from the forage sample was accompanied by the accumulation of FAAs in the buffer (Fig. 1). At 24 h, FAAs recovered were $16.8 \%$ (se \pm $0.034 \%$ ) of the $\mathrm{N}$ present at the beginning of the incubation. These data indicate that proteolytic enzymes within the forage contribute to total proteolysis when intact plant cells in leaf fragments are subjected to conditions mimicking those found in the rumen. The $\mathrm{N}$ recovered as FAAs accounted for only $75 \%$ of the $\mathrm{N}$ lost after $24 \mathrm{~h}$ in sacco (Fig. 1). This may be due to a portion of the degraded $\mathrm{N}$ adhering to the recovered samples being subsequently lost during the rinsing process prior to $\mathrm{N}$ measurement, or to experimental error. Other research has shown $94 \%$ recovery of lost $\mathrm{N}$ as FAAs using more finely chopped $(5 \mathrm{~mm})$ perennial ryegrass

Figure 1 Plant-mediated proteolysis (closed symbols) in fresh herbage samples incubated in sacco, and the recovery of free amino acids (open symbols) in the incubation buffer. Plant-mediated proteolysis data are total $\mathrm{N}$ as measured by combustion. Values are mean \pm standard errors of total $\mathrm{N}$ recovered from two replicates in each of two cows.

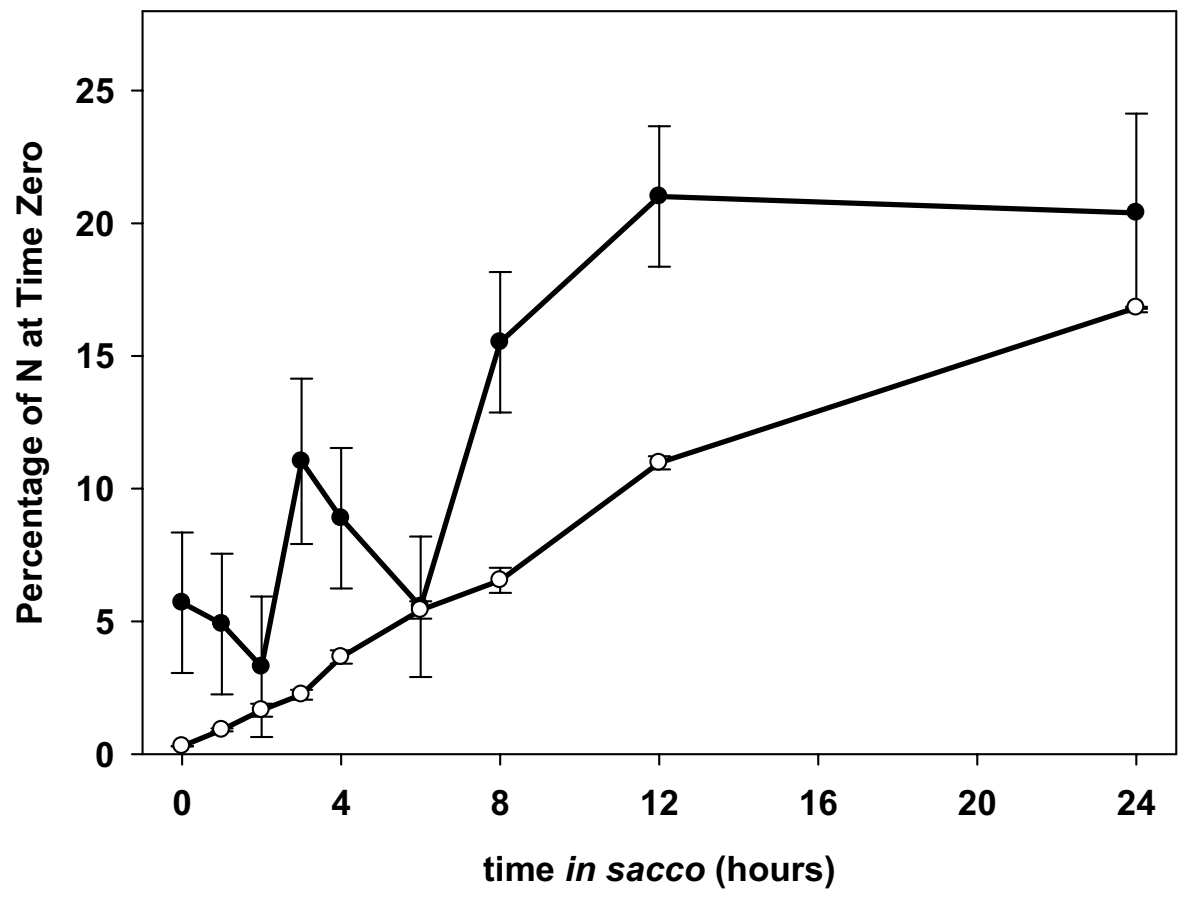


Figure 2 Plant-mediated proteolysis (closed symbols) and total proteolysis (open symbols) in chopped fresh perennial ryegrass leaves incubated in sacco. Values are mean \pm standard errors of total $\mathrm{N}$ recovered from two replicates in each of two cows.

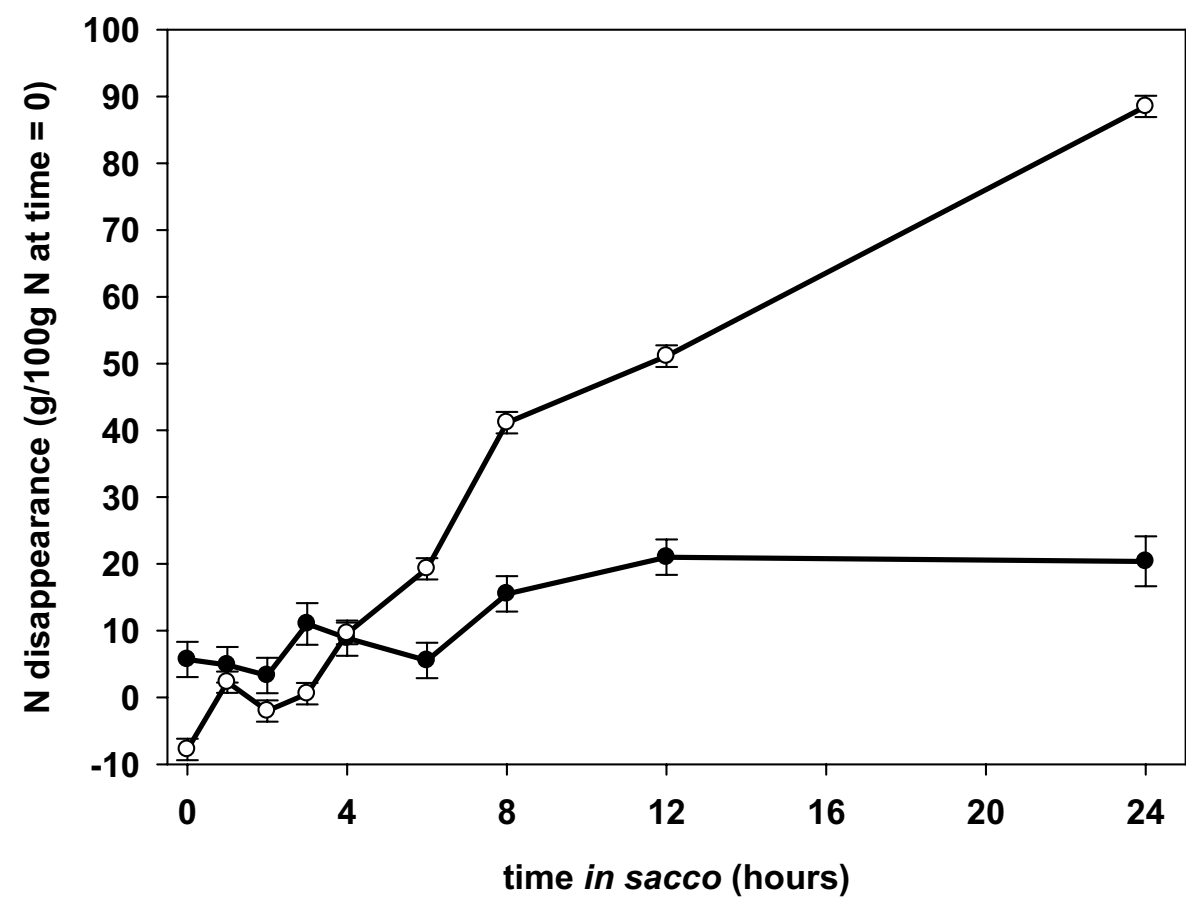

leaf segments (Beha et al. 2002).

Comparisons with the samples which were exposed to rumen microbes suggest that rates of $\mathrm{N}$ loss were similar and low for the first 4 hours in sacco. After 12 hours, $50 \%$ of total $\mathrm{N}$ was lost from the samples exposed to rumen microbes, whereas $20 \%$ of total $\mathrm{N}$ was lost from the PMP treatment (Fig. 2). These findings suggest up to $40 \%$ of the total proteolysis for intact plant cells in leaf fragments over the first 12 hours in sacco is caused by PMP.

The finding that largely intact plant cells are metabolically active in sacco is relevant in light of the fact that the majority of forage $\mathrm{N}$ remains within plant cells during ingestion, and that a number of plant cells remain intact within ingested leaf fragments. Research in animals grazing pasture has shown that $68 \%$ of $\mathrm{N}$ is not released during ingestion, and that $74 \%$ of ingested grass fragments recovered from boli were $>2 \mathrm{~mm}$ in size (Boudon et al. 2004). New Zealand research has shown that 17.5 hours after dairy cows consume a ryegrass meal, $31 \%$ of dry matter in the rumen does not pass a 4 mm sieve (Waghorn et al. 1989), suggesting that a substantial proportion of grazed forage plant cells enter the rumen intact, and remain in multi-cellular leaf fragments for a significant time period.

The deliberate use of coarse-chopped fresh forage ensured that a high proportion of plant cells remained intact in leaf fragments, allowing better observation of the plant response to the rumen environment. Our use of chopped fresh forage reflects the methods used by overseas researchers (Kingston-Smith et al. 2005), a marked departure from many in sacco and in vitro experimental approaches, which often rely on frozen minced or inert dried and milled samples for ease of handling large sample numbers. While frozen minced samples mimic the particle size distribution of a sheep or cow rumen, they are not a perfect analogue for the metabolic properties of freshly ingested forage, as plant cell damage in a freeze-thaw cycle may influence the plant metabolic response to the rumen environment. Inert dried and milled samples are even less representative of intact plant cells in fresh grazed herbage. We recognise that our experimental design will lead to a high estimate of potential PMP. This estimate should not be construed as an estimate of actual PMP in grazing animals. However it provides data comparable to those in the literature (Kingston-Smith et al. 2005), and allows better separation of the effects of intrinsic plant proteolytic processes per se from effects induced by plant cell damage and microbial invasion.

\section{Genetic variation for plant-mediated proteolysis}

The percentage of total $\mathrm{N}$ remaining in samples after 24 hours in vitro in the absence of rumen microbes differed 
Table 1 Effect of cultivar on plant-mediated proteolysis and dry matter disappearance among five perennial ryegrass cultivars incubated in vitro in the absence of rumen microbes. Nitrogen remaining is total $\mathrm{N}$ after 24 hours in vitro, expressed as a percentage of the total $\mathrm{N}$ at time zero. Dry matter remaining is the percentage of the total dry matter at time zero remaining after 24 hours in vitro. Different letters within columns indicate statistically significant $(P<0.05)$ effects.

\begin{tabular}{lcc}
\hline Cultivar & N remaining (\%) & DM remaining (\%) \\
\hline A & $73.5^{\mathrm{ab}}$ & $72.5^{\mathrm{a}}$ \\
$\mathrm{B}$ & $76.9^{\mathrm{a}}$ & $73.4^{\mathrm{a}}$ \\
C & $67.4^{\mathrm{b}}$ & $72.1^{\mathrm{a}}$ \\
$\mathrm{D}$ & $74.6^{\mathrm{ab}}$ & $73.5^{\mathrm{a}}$ \\
E & $77.0^{\mathrm{a}}$ & $70.1^{\mathrm{a}}$ \\
\hline SED & 2.13 & 1.40 \\
\hline
\end{tabular}

significantly $(\mathrm{P}<0.05)$ for one of the five perennial ryegrass cultivars sampled (Table 1). Cultivars did not significantly differ in percent dry matter remaining after 24 hours. The differences in PMP among cultivars are a further indication that plant metabolic processes may contribute to proteolysis in the rumen, and suggest there may be opportunity to select for a reduced rate or extent of PMP.

Significant $(\mathrm{P}<0.05)$ variation in the extent of PMP among replicated samples of 12 individual genotypes within each of two cultivars (B and $\mathrm{C}$ in the previous experiment) was observed after 24 hours in vitro. Among genotypes within Cultivar $\mathrm{B}$, mean total $\mathrm{N}$ remaining ranged from 62 to $86 \%$. A similar range (59-77\%) was observed within Cultivar C. There was no correlation between the percent $\mathrm{N}$ remaining and the initial $\mathrm{N}$ concentration of the forage $\left(r^{2}=0.06\right)$. Genotypes within cultivar did not differ significantly in percent dry matter remaining.

\section{Conclusion}

These experiments indicate the PMP occurs in sacco, and that variation for PMP exists among and within cultivars. This leads us to concur with others that there may be opportunities for plant breeding to reduce PMP and improve rumen function with respect to $\mathrm{N}$ utilisation (Kingston-Smith \& Thomas 2003), complementing those opportunities offered by increases in the levels of fructans, and chemical chaperones such as the condensed tannins. However, it must first be empirically determined whether or not inherent differences in PMP lead to net changes in total protein degradation in the rumen, and whether these changes are manifest as changes in $\mathrm{N}$ partitioning in the rumen and ruminant.

Should further experiments indicate that variation in PMP results in net changes in the $\mathrm{N}$ economy of the rumen, the immediate opportunities for the pastoral sector include utilising current forage grass cultivars with greater protein stability, and investigating farm management practices to enhance protein stability realised from grazed fresh forage. Longer term opportunities may exist for selective breeding to develop high merit forage grasses with enhanced protein stability. In total, these research outcomes may join an array of technologies available to the pastoral sector to overcome the detrimental impact of rapid solubilisation and degradation of grazed forage $\mathrm{N}$ in the rumen.

\section{ACKNOWLEDGEMENTS}

This research was funded by New Zealand dairy farmers through Dairy InSight project FD607. The authors are grateful to Tom Lyons, Tony Dunn, Matt Deighton, Peter Schreurs, Connie Neblung, and Kate Lowe for their technical assistance in the research programme.

\section{REFERENCES}

Attwood, G. 2005. The contribution of plant-derived proteinases to the breakdown of fresh pasture protein in the rumen. British Journal of Nutrition 93: 421423.

Beha, E.M.; Theodorou, M.K.; Thomas, B.J.; KingstonSmith, A.H. 2002. Grass cells ingested by ruminants undergo autolysis which differs from senescence: implications for grass breeding targets and livestock production. Plant, Cell and Environment 25: 12991312.

Boudon, A.; Acosta, A.; Delagarde, R.; Peyraud, J.L. 2004. Effect of grazing versus indoors feeding on the damage done to the grass during ingestive mastication. Journal of Animal and Feed Sciences 13: 35-38.

Edwards, G.R.; Parsons, A.J.; Rasmussen, S.; Bryant, R.H. 2007. High sugar ryegrasses for livestock systems in New Zealand. Proceedings of the New Zealand Grassland Association 69: 161-171.

Kingston-Smith, A.H.; Bollard, A.L.; Armstead, I.P.; Thomas, B.J.; Theodorou, M.K. 2003. Proteolysis and cell death in clover leaves is induced by grazing. Protoplasma V220: 119-129.

Kingston-Smith, A.H.; Merry, R.J.; Leemans, D.K.; Thomas, H.; Theodorou, M.K. 2005. Evidence in support of a role for plant-mediated proteolysis in the rumens of grazing animals British Journal of Nutrition 93: 73-79.

Kingston-Smith, A.H.; Thomas, H.M. 2003. Strategies of plant breeding for improved rumen function. Annals of Applied Biology 142: 13-24.

Lee, M.R.F.; Colmenero, J.D.O.; Winters, A.L.; Scollan, N.D.; Minchin, F.R. 2006. Polyphenol oxidase activity in grass and its effect on plant-mediated lipolysis and proteolysis of Dactylis glomerata (cocksfoot) in a 
simulated rumen environment. Journal of the Science of Food and Agriculture 86: 1503-1511.

Ulyatt, M.J. 1981. The feeding value of herbage: Can it be improved? New Zealand Agricultural Science 15: 200-205.

Ulyatt, M.J. 1997. Can protein utilisation from pasture be improved? Proceedings of the New Zealand Society of Animal Production 57: 4-8.

Waghorn, G.C.; Shelton, I.D.; Thomas, V.J. 1989. Particle breakdown and rumen digestion of fresh ryegrass (Lolium perenne L.) and lucerne (Medicago sativa L.) fed to cows during a restricted feeding period. British Journal of Nutrition 61: 409-423.

Wang, Y.; Douglas, G.B.; Waghorn, G.; Barry, T.N.;
Foote, A.G. 1996. Effect of condensed tannins in Lotus corniculatus upon lactation performance in ewes. Journal of Agricultural Science 126: 353-362.

Woodward, S.L.; Auldist, M.J.; Laboyrie, P.J.; Jansen, E.B.L. 1999. Effect of Lotus corniculatus and condensed tannins on milk yield and milk composition of dairy cows. Proceedings of the New Zealand Society of Animal Production 59: 152-155.

Zhu, W.Y.; Kingston-Smith, A.H.; Troncoso, D.; Merry, R.J.; Davies, D.R.; Pichard, G.; Thomas, H.; Theodorou, M.K. 1999. Evidence of a role for plant proteases in the degradation of herbage proteins in the rumen of grazing cattle. Journal of Dairy Science 82: 2651-2658. 